\title{
Teachers' Perspectives and Practices in Applying Technology to Enhance Learning in the Classroom
}

\author{
http://dx.doi.org/10.3991/ijet.v10i3.4356 \\ T. S. Safitry ${ }^{1}$, T. Mantoro ${ }^{2}$, M. A. Ayu ${ }^{2}$, I. Mayumi ${ }^{1}$, R. Dewanti ${ }^{1}$, S. Azmeela ${ }^{3}$ \\ ${ }^{1}$ University of Jakarta, Jakarta, Indonesia \\ ${ }^{2}$ Universitas Siswa Bangsa Internasional, Jakarta, Indonesia \\ ${ }^{3}$ Universiti Teknologi Malaysia, Kuala Lumpur, Malaysia
}

\begin{abstract}
Over the past decade, teachers are becoming more familiar with the use of Information Communication Technology (ICT) in the classrooms. Many studies have shown the benefits of using ICT in classrooms. However, there are evidence that the ICT reform efforts have failed because the teacher's beliefs, skills, and attitudes were never taken into consideration. Studies shows that most research only focuses on students' opinion towards ICT. Besides that, this study tries to investigate the teachers' perspectives and practices towards the use of ICT in the classrooms. A survey was conducted to collect the data. Using a revised expectancy-value theory called the Technology Implementation Questionnaire (TIQ), a questionnaire was administered to 20 elementary teachers from the public schools sector in Depok, West Java. The findings revealed that there are teachers with more than 10 years of teaching experience but never got any formal training on using ICT. Overall, the teachers have a positive perspective towards applying ICT in their classrooms, even though they lack of technical support from the schools and lack of ICT proficiency. .
\end{abstract}

Index Terms-ICT, Teachers' perspectives and practices, Technology Implementation Questionnaire (TIQ).

\section{INTRODUCTION}

In recent years, the use of Information Communication Technology or ICT's has been identified to have a significant role in improving education (Kozma \& Anderson, 2002; Pelgrum, 2001; Hennessy, Ruthven, \& Brindley, 2005; Goodison, 2003; Kangro \& Kangro, 2004; cited by Papanastasiou \& Angeli, 2008). As Yusuf (2005) stated in his study, the field of education has been affected by ICT, which means it is affecting teaching, learning and research. Gulbahar \& Guven (2008) also said that the integration of ICT can aid teacher' and students' revitalization, this can improve and develop the quality of education by providing curricular support in difficult subject areas. Moreover, a study shows that the quality of learning can be greatly enhanced through the integration of ITC in teaching (Davies, 2007).

Seeing many benefits that can be achieved in applying ICT in the education field, The Ministry of Education in Indonesia has a purpose to improve the quality of education through enriching the learning environment with the help of ICT. It is related with the objectives of the ministry in regulation Act. No.14 of 2005 on teachers and lectures that states in carrying out the task of professional- ism, teachers and lecturers are obliged to "improve and develop academic qualification and competence on an ongoing basis in line with the development of science, technology and art". In other words, the teachers are expected to be more professional by developing their competences in those parts, especially in technology.

However, some research evidences indicate that the integration of ICT in the classrooms is problematic (Noble, 1998; Russel, 1999; cited by Wozney, Venkatesh and Abram, 2006). It is also identified that the ICT reform efforts have failed because teachers' beliefs, skills and attitudes never taken into consideration, the researchs show that many studies only concern on the students' behalf. (Cuban, 2000; Becker \& Ravitz, 1999; Bosch \& Cardinale, 1993; Brush, 1998; Darling-Hammond, 1990; Ely, 1995; Hunt \& Bohlin, 1995; cited by Papanastasiou \& Angeli, 2008).

Therefore, related with this matter, there is a need to the researcher to conduct a research in order to investigate teachers' perspectives and practices regarding with the use ICT in the classroom. The researcher also wants to know in which aspects of the teachers are lacking in the use of ICT. Using a theory called the Technology Implementation Questionnaire (TIQ) proposed by Wozney, Venkatesh and Abram (2006) that has been revised and suited with the purpose of this research; the researcher collects the data using questionnaires that consist with 4 sections: teachers' backgrounds, teachers' proficiencies and practices, teachers' perspectives and teachers' obstacles and challenges in using ICT. Hopefully the result of this research can give some contribution as the representation of implementing the use of ICT from the teachers' point of views.

\section{RELATED WORK}

\section{A. The Benefits of ICT}

Some researchers found that the use of ICT in classrooms has increased because it has many benefits in the field of education. A study from Tella, Tella Toyobo, Adika \& Adeyinka (2007) cited by Hennessy et al. (2010) found that teachers in Nigeria perceived ICT as a very useful way to make the process of teaching and learning become easier.

ICT has become agent of change and innovation in the educational field (Williams, 2003). Moreover, ICT also 
can be seen as important tool to "innovate, accelerate, enrich, and deepen skills, to motivate and engage students, to help relate school experience to work practices, create economic viability for tomorrow's workers, as well as strengthening teaching and helping schools change" (Davis and Tearle, 1999; Lemke and Coughlin, 1998; cited by Yusuf, 2005).

\section{B. Teachers' Perspectives and Practices towards ICT}

A study from Kandasamy and Shah (2013) found that the respondents, teachers' from Malaysia, have positive attitudes towards using ICT. As majority of the respondents used that to teach computer skills, communicate with colleagues, monitor students' performance and have presentations. A survey study that they conducted also mentioned that teachers are lacking of time in school to use of ICT.

Melor (2007), conducted a study about Malaysian ESL teachers' use of ICT in their classrooms. The study found that ESL teachers have positive perspective but still lacks in skills as they are not well versed with many new software and limited infrastructure. Teachers too, are lacking in trainings as well as expertise to offer help and guidance to enhance the learning process.

A similar research was done Pamela and Noraza (2007) to find out the teachers' views on ICT and how ICT can help them in teaching. The result indicated that all teachers has same believe that ICT is an important and useful tool to help them convey or present their teaching as students are more looking forward to go to classes conducted with multimedia than to go to traditional or conventional method one.

Findings by Erdogan (2010) shows that the most of widely used ICT type among Turkish' teachers is the Internet, and it was followed by word processing. The results also mentioned that teachers had a high level of knowledge about software but low level of information of most software. The teachers who have low level in using technology confirmed as those who never receive any formal training. Therefore, these clearly show that training is important to teachers.

\section{Methodology In Applying ICT to ENHANCE LEARNING IN THE CLASSROOM}

\section{A. Research Design}

The study used a questionnaire in order to collect the data. The questionnaire was designed by adopting the theory called Technology Implementation Questionnaire (TIQ) proposed by Wozney, Venkatesh and Abram (2006) and Kandasamy and Shah's questionnaires (2013) that has been revised and suited with the purpose of this study. The purpose was to gain more information that can be recommended to uphold the education system integrating ICT.

\section{B. Location}

The study was done in Depok, West Java, Indonesia. It is situated near the capital city of Indonesia: Jakarta. Depok is a city that borders with South Jakarta. Cipayung is one of the districts in Depok that has schools from the urban and sub rural area.

\section{Population and Sample}

The population of the study is approximately 30 elementary school teachers in Cipayung, Depok, West Java. The population is quite big, therefore the random stratified sampling is used as the respondents of the study.

It is supported by the statement that "stratification is the process of grouping the members of a population into relatively homogenous strata before sampling. Stratified sampling decreases the error than simple random sampling and systematic sampling. Simple random sampling and systematic sampling both ensure a degree of representativeness and permit an estimate of the error present. Stratified sampling is a method for obtaining a greater degree of representativeness -decreasing the probable sampling error" (Babbie, 1995 cited by Kandasamy and Shah, 2013).

\section{Instrument}

The questionnarie was divided into 4 sections:

\section{1) Section 1: Teachers' background}

In this part, gender, teaching experience, how long they use computer and teachers' received formal training in ICT were the questions that have been asked.

\section{2) Section 2: Teachers' proficiencies and practices}

In this part the respondents were asked their knowledge in using softwere. They could choose either on excellent, good, fair or no capability. They also were asked how frequent do they use ICT such as instructional tools and manuals and their practices in using ICT for educational purposes. The options were always, often, rarely and never.

\section{3) Section 3: Teachers' perspectives}

In this part, the respondents answered the questions regarding with their opinions towards their perspectives upon ICT. The scales were ranked from disagree, neutral, agree and completely agree.

\section{4) Section 4: Obstacles and Challenges in using ICT}

In this part the obstacles and challenges that the respondents faced were asked with the rated as disagree, neutral, agree and completely agree.

\section{E. Data Collection}

The questionnaires were distributed to the schools. There were around 30 questionnaires that were delivered but only 20 that can be a study sample.

\section{F. Data Analysis}

The data was analyzed using Likert scale to obtain the research statistic. The researcher also used descriptive statistics to explain each of the sections.

\section{FINDING \& DISCUSSION}

In this part of the study, the findings are reported in a sequence of the sections in the questionnaires that have been distributed.

The first section is about the background of the teachers that has been investigated. 


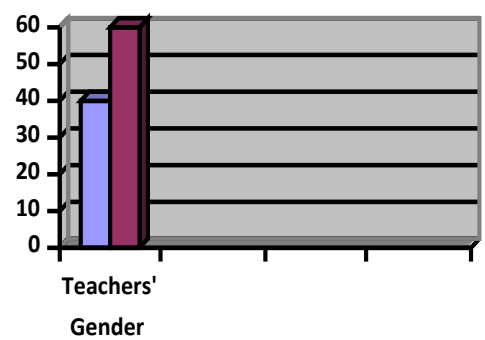

Figure 1. Teachers' background: Gender

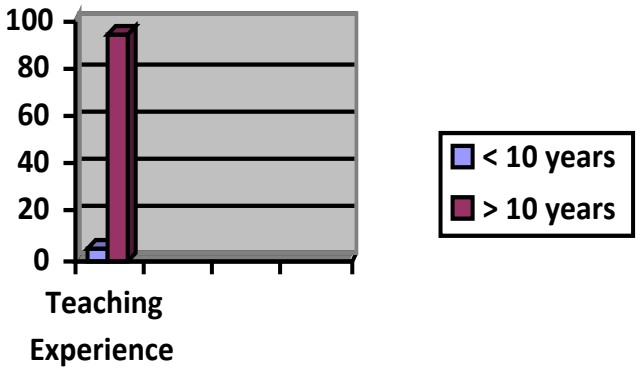

Figure 2. Teachers' background: Teaching experience

From Figure 1 to 4 , it can be seen that most of the respondents in this survey are females who represent $60 \%$ of the sample and $40 \%$ of the respondents are males. As for the teaching experience, almost all of them have more than 10 years experiencing as a teacher, there are $95 \%$ teachers, while only $5 \%$ who have less than 10 years experiences in teaching. Then, there are $50 \%$ teachers who have been using computer for more than 2 years, $40 \%$ who have been using computer for less than 2 years, and $10 \%$ of respondents don't answer the question. The majority of the respondents $25 \%$ have received formal training, $55 \%$ do not receive any formal training computers, and $20 \%$ do not answer the questions.

The second sections reveal the teachers' proficiencies and practices toward the use of ICT. The subsection A is about the proficiency in using software. The respondents are rated from excellent, good, fair and no capability (Table I).

The results shows that there are about $45 \%$ of respondents who have fair capacity in using Word processor such as MS. Word, 30\% have no capability, 20\% have good capability and only 5\% who have excellent capability in using the software. Meanwhile for Spreadsheet software like MS. Excel, most of the teacher about $40 \%$ having no capability in using that, only $30 \%$ have fair proficiency and $25 \%$ good proficiency and only $5 \%$ who have excellent proficiency. Next, it states there are the presentation software such as PowerPoint $40 \%$ respondents has no capability, $30 \%$ have fair capability, $25 \%$ have good capability, and $5 \%$ have excellent capability. About Web Browser like majority of respondent around $60 \%$ have no capability in using this; around $20 \%$ have good and fair capability. Then, as for search engines there are $50 \%$ who have no capability, $35 \%$ with fair capability, $10 \%$ and $5 \%$ with good and excellent capability. $30 \%$ of the respondents have good proficiency in using E-Mail, but there are $50 \%$ who have no capability in using that, and $31 \%$ who have fair capability, and only $5 \%$ who have excellent proficiency. The last is for using art software like paint or
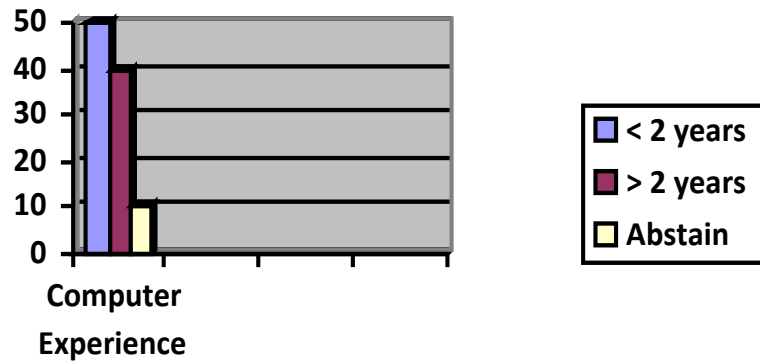

Figure 3. Teachers' background: Computer experience
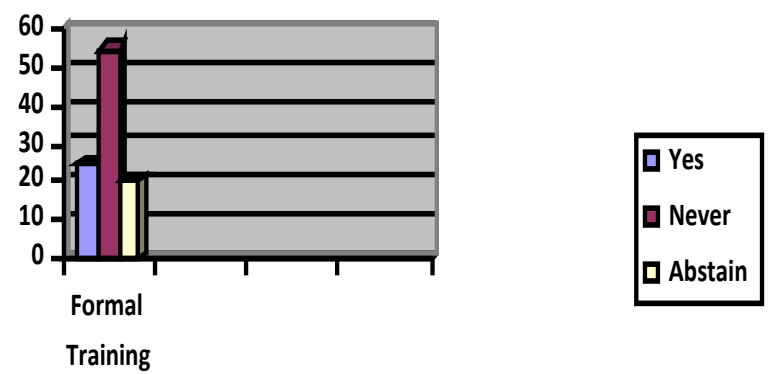

Figure 4. Teachers' background: Formal training received in using ICT

TABLE I.

SOFTWARE USAGE

\begin{tabular}{|c|c|c|c|c|}
\hline \multirow{2}{*}{ Software Usage } & \multicolumn{4}{|c|}{ Proficiency (\%) } \\
\cline { 2 - 5 } & Excellent & Good & Fair & No capability \\
\hline Word Processor & .5 & .20 & .45 & .30 \\
\hline Spreadsheet & .5 & .25 & .30 & .40 \\
\hline $\begin{array}{c}\text { Presentation } \\
\text { software }\end{array}$ & .5 & .25 & .30 & .40 \\
\hline Web Browser & & .20 & .20 & .60 \\
\hline Search Engines & .5 & .10 & .35 & .50 \\
\hline E-Mail & .5 & .30 & .31 & .55 \\
\hline Arts & & .10 & .20 & .70 \\
\hline
\end{tabular}

TABLE II.

USAGE OF INSTRUCTIONAL TOOLS AND MATERIALS

\begin{tabular}{|c|c|c|c|c|}
\hline \multirow{2}{*}{ Tools and Materials } & \multicolumn{4}{|c|}{ Practices (\%) } \\
\cline { 2 - 5 } & Always & Often & Rarely & Never \\
\hline Board & .60 & .40 & & \\
\hline Computer & & .30 & .55 & .35 \\
\hline Computer- Projector & & .15 & .45 & .35 \\
\hline Radio Cassette & & .20 & .50 & .30 \\
\hline Television & & .10 & .50 & .45 \\
\hline Video Camera & & .15 & .30 & .55 \\
\hline OHP & & .15 & .35 & .45 \\
\hline Printed Materials & .20 & .25 & .25 & .30 \\
\hline
\end{tabular}

Photoshop, here most of the respondents say they cannot use it, they are around $70 \%$, and only $10 \%$ have good capability and $20 \%$ have fair capability in using it.

The subsection B is about teachers' practices in their classroom activities in using tools and materials. The result is shown in Table II.

Table II shows that there are $60 \%$ of the teachers always use board as an instructional tool, and $40 \%$ of them answered with often. The use of computer in the class- 
room is $45 \%$ teachers answer rarely, $30 \%$ is often and $35 \%$ of them are never using it. As for radio cassette, around $50 \%$ answer they rarely use it, $20 \%$ are often use it, and $30 \%$ of them says never use it. The use of TV is about $50 \%$ of the respondents is rarely using it, $45 \%$ never use it, and $15 \%$ often use it. While there are $55 \%$ teachers never use camera as the media, only $15 \%$ often use it and $35 \%$ rarely use it. About $45 \%$ of the respondents never use OHP, $35 \%$ of them rarely use it, and only $15 \%$ often use it. Then, there are $20 \%$ of them that use printed materials while teaching, $25 \%$ say they are often and rarely use it and $30 \%$ states that they never use it.

The subsection $\mathrm{C}$ is about the level of ICT used for educational purposes by teachers.

Table III shows the result of ICT used for educational purposes by teachers. $50 \%$ respondents responded that they rarely use it for teaching and learning strategic. There are $45 \%$ respondents often use it for teaching computer skills. The majority of them, $55 \%$ use it to find and access information and educational materials. While only $45 \%$ said they often use it, and $45 \%$ also say rarely. $50 \%$ of the respondents often use it for preparing lesson. While, $40 \%$ always use it for communicating with students, and 50\% always use it for communicating with other teachers. Most of them, around $80 \%$ often use the ICT for monitoring and evaluating students' progress, while only $50 \%$ are often used for keeping track students' performance. $30 \%$ of them always use it for preparing reports, and 40\% rarely use it for the same purpose.

Furthermore, the third sections deals with teachers' perspectives towards ICT.

In the Table IV, the majority of respondents around $70 \%$ agree that they feel comfortable using ICT as a tool in teaching and learning. But they also say $50 \%$ of them agree that the use of ICT is kind of stresses them out. $40 \%$ of them disagree about the statement if something wrong with ICT they don't know how to fix it, it means some of them know how to fix it if there is something wrong. $70 \%$ of them agree that the use of ICT is fascinating and interesting. They also agree, around $50 \%$ of them, that computer is very useful for teaching. The statement of computer helps students understand concepts in a more effective way is agreed by $50 \%$ of the respondents and completely agree by $40 \%$ respondents respectively. The majority of the respondents, $50 \%$ agree and $40 \%$ completely agree that computer helps teachers to teach in more effective ways. More than half which is $55 \%$ of the respondents agree that computer is not conducive to good teaching because it creates technical problems and $40 \%$ completely agree with that but only $5 \%$ of the respondents disagree with the statement.

The last section is about some obstacles and challenges faced by teachers in using ICT (Table V).

The correspondents have answered that they completely agree that the lack of technical support becomes the obstacle, i.e. $65 \%$. They also claim that $65 \%$ of them having lack of time in school to use the ICT. $50 \%$ of them completely agree that they have limited knowledge on how to make full use of ICT. Around $65 \%$ state that they have limited understanding on how to integrate ICT into teaching. Most of them, $80 \%$ state that they have lack knowledge of software and websites to support teaching and learning.
TABLE III.

LEVEL OF ICT USED FOR EDUCATIONAL PURPOSES BY TEACHERS.

\begin{tabular}{|c|c|c|c|c|}
\hline \multirow{2}{*}{ Items } & \multicolumn{4}{|c|}{ Practices } \\
\cline { 2 - 5 } & Always & Often & Rarely & Never \\
\hline $\begin{array}{c}\text { Teaching-learning for specif- } \\
\text { ic subject }\end{array}$ & .50 & .50 & \\
\hline Teaching computer skills & .10 & .45 & .40 & .5 \\
\hline $\begin{array}{c}\text { Finding and accessing infor- } \\
\text { mation and educational } \\
\text { materials }\end{array}$ & .5 & .55 & .40 & \\
\hline Making presentation & .25 & .50 & .25 & .10 \\
\hline Preparing lesson & .40 & .40 & .15 & .5 \\
\hline Communicating with students & .55 & .25 & .15 & \\
\hline $\begin{array}{c}\text { Communicating with other } \\
\text { teachers }\end{array}$ & .15 & .80 & .5 & \\
\hline $\begin{array}{c}\text { Monitoring and evaluating } \\
\text { students' progress }\end{array}$ & .25 & .50 & .25 & .45 \\
\hline $\begin{array}{c}\text { Keeping track students' } \\
\text { performance }\end{array}$ & .30 & .25 & .40 & \\
\hline \begin{tabular}{c} 
Preparing reports \\
\hline
\end{tabular} & & .45 & & \\
\hline
\end{tabular}

TABLE IV.

TEACHERS’ PERSPECTIVE TOWARDS ICT

\begin{tabular}{|c|c|c|c|c|}
\hline \multirow{2}{*}{ Items } & \multicolumn{4}{|c|}{ Teachers' Perspectives } \\
\cline { 2 - 5 }$(\%)$ & \multicolumn{1}{|c|}{ (\% } & $A$ & $N$ & $D A$ \\
\hline $\begin{array}{c}\text { I feel comfortable using ICT as a tool in } \\
\text { teaching and learning }\end{array}$ & .30 & .70 & & \\
\hline The use of computer stresses me out & .40 & .50 & & .10 \\
\hline $\begin{array}{c}\text { If something goes wrong I will not } \\
\text { know how to fix it }\end{array}$ & .5 & .20 & .35 & .40 \\
\hline $\begin{array}{c}\text { The use of ICT in teaching and learning } \\
\text { excites me }\end{array}$ & .25 & .70 & .5 & \\
\hline $\begin{array}{c}\text { The computer is a valuable tool for } \\
\text { teachers }\end{array}$ & .55 & .40 & .5 & \\
\hline $\begin{array}{c}\text { The computer will change the way } \\
\text { students learn in my classes }\end{array}$ & .40 & .50 & .10 & \\
\hline $\begin{array}{c}\text { The ICT is not conducive to student } \\
\text { learning because it is not easy to use }\end{array}$ & & .10 & .45 & .45 \\
\hline $\begin{array}{c}\text { The computer helps students understand } \\
\text { concepts in more effective ways }\end{array}$ & .40 & .50 & .10 & \\
\hline $\begin{array}{c}\text { The computer is not conducive to good } \\
\text { teaching because it creates technical } \\
\text { problems }\end{array}$ & .40 & .55 & & .5 \\
\hline $\begin{array}{c}\text { The } \\
\text { Thyyyy}\end{array}$ & & & & \\
\hline
\end{tabular}

TABLE V.

THE OBSTACLES OR CHALLENGES FACED BY TEACHERS IN USING ICT

\begin{tabular}{|c|c|c|c|c|}
\hline \multirow{2}{*}{ Items } & \multicolumn{4}{|c|}{ Obstacles and Challenges } \\
\cline { 2 - 5 } & $C A$ & $A$ & $N$ & $D A$ \\
\hline Lack of technical support & .65 & .20 & .10 & .5 \\
\hline Lack of time in school & .20 & .65 & .10 & .5 \\
\hline $\begin{array}{c}\text { Limited knowledge on how to } \\
\text { make full use of ICT }\end{array}$ & .50 & .30 & .20 & \\
\hline $\begin{array}{c}\text { Limited understanding on how to } \\
\text { integrate ICT into teaching }\end{array}$ & .65 & .35 & & \\
\hline $\begin{array}{c}\text { Lack of software or websites that } \\
\text { support teaching and learning }\end{array}$ & .80 & .20 & & \\
\hline Scale: DA-Disagree N-Neutral A-Agree CA-Completely Agree \\
\hline
\end{tabular}




\section{CONCLUSIONS}

The findings of this research shows that most of the teachers with more than 10 years of teaching experience have never have attended a formal training in using ICT. Therefore, this influences how they can grasp and adopt the knowledge of using ICT. Some of them (40\%), still lack the capability of using software like Ms. PowerPoint or Ms. Excel. Then it will affect the learning itself, since now the use of PowerPoint is being one of the most recommended one to the teacher.

Even though nearly all of the teachers stated they feel comfortable in using ICT, some of them also agree that using ICT in the classroom activity makes them feel depressed. Problems appear due to the lack of knowledge on how to apply ICT and the knowledge about software/website to support teaching and also the lack of technical support from the schools.

But excuses are no longer accepted, and it is time for all the teachers to gear up and learn the required skills and knowledge on ICT. Having a positive perspective on something can help teachers to improve their self periodically.

This study also concludes that policy makers who are responsible in formulating the policies related with teaching and learning should make the appropriate and responsive policies to the needs of teachers.

\section{REFERENCES}

[1] Davis, N.E., \& Tearle, P. (Eds.). (1999). A core curriculum for telematics in teacher training. Available: www.ex.ac.uk/ telematics.T3/corecurr/tteach98.htm

[2] Gulbahar, Y., \& Guven, I. (2008). A Survey on ICT Usage and the Perceptions of Social Studies Teachers in Turkey. Educational Technology \& Society, 11 (3), 37-51.

[3] Hennessy, S., Ruthven, K. \& Brindley, S. (2005). Teacher perspectives on integrating ICT into subject teaching: commitment, constraints, caution, and change. Journal of Curriculum Studies, 37(2), 155-192. http://dx.doi.org/10.1080/0022027032000276961

[4] Kangro, A. \& Kangro, I. (2004). Integration of ICT in Teacher Education and Different School Subjects in Latvia. Educational Media International, 41(1), 31-37. http://dx.doi.org/10.1080/ 0952398032000105076
[5] Kozma, R. \& Anderson R. E. (2002). Qualitative case studies of innovative pedagogical practices using ICT. Journal of Computer Assisted Learning, 18, 387-394. http://dx.doi.org/10.1046/j.02664909.2002.00250.doc.X

[6] Melor Md Yunus. (2007). Malaysian ESL teachers' use of ICT in their classrooms: expectations and realities. European Association for Computer Assisted Language Learning. ReCALL 19(1):79-95 http://dx.doi.org/10.1017/s0958344007000614

[7] Pamela, K. (2006). Factors affecting the online delivery of English Language Courses in a virtual learning environment, UPM, Jilid 2, Bilangan 2.

[8] Papanastasiou, E. C., \& Angeli, C. (2008). Evaluating the Use of ICT in Education: Psychometric Properties of the Survey of Factors Affecting Teachers Teaching with Technology (SFA-T3). Educational Technology \& Society, 11 (1), 69-86.

[9] Pelgrum, W. (2001). Obstacles to the integration of ICT in education: Results from a worldwide educational assessment. Computers \& Education, 37, 163-178. http://dx.doi.org/10.1016/S03601315(01)00045-8

[10] Russell, G. \& Bradley, G. (1997). Teachers' computer anxiety: Implications for professional development. Education and Information Technologies, 2, 17-30. http://dx.doi.org/10.1023/A:1 018680322904

[11] Williams, J. (2003). Computers and project-based learning. Media \& Methods Magazine - Philadelphia, PA, USA. Retrieved June 3, 2010, from http://www.media-methods.com.

[12] Yusuf, M.O. (2005). Information and communication education: Analyzing the Nigerian national policy for information Technology. International Education Journal Vol. 6 No. (3), Pp; 316-321.

\section{AUTHORS}

Tantri Sari Safitry, Ilza Mayumi and Ratna Dewanti are with Faculty of Languages and Arts, State University of, Jakarta, Indonesia.

Teddy Mantoro and Media A. Ayu are with Faculty of Science and Technology, Universitas Siswa Bangsa Internasional, Jakarta, Indonesia.

Sya Azmeela is with Advanced Informatics School, Universiti Teknologi Malaysia, Kuala Lumpur, Malaysia.

Submitted 31 December 2014. Published as resubmitted by the authors 11 May 2015. 